\title{
Tax Accounting for Livestock: Mother or Meat/Capital or Revenue?
}

\section{ALEXANDER FULLARTON* AND DALE PINTO**}

Adjunct Professor and Professor, Curtin Law School, Curtin University, respectively.

Australia is experiencing cataclysmic weather events largely due to rising atmospheric temperatures caused by greenhouse gas emissions - climate change. A consequence of droughts, floods, fires, tempests and family disasters is the sale or loss of valuable stud stock. In normal trading circumstances, these animals would not be sold as trading stock. However, the sale of pastoral properties can be beyond the will of the owners for a raft of reasons.

Presently, the receipts from the sale of ALL animals sold as part of a primary production business are income, according to ordinary concepts of the Australia Taxation Office (ATO) and they are taxed at ordinary income tax rates.

This article considers the value of animals included in the sale of rural properties in Australia. It argues that the provisions of the Income Tax Assessment Act 1997 are being misinterpreted by tax administrators and tax professionals. Considering the sale of ALL animals traded during the sale of a pastoral lease or farm as revenue denies vendors of concessions permitted under the capital gains tax provisions. This article examines the income and capital gains tax implications on the sale of animals in conjunction with the sale of pastoral and farming properties in Australia. The distinction between classifying expenditure by an enterprise to be on items of a capital or a revenue nature has long been argued. Generally, in accounting terms, expenditure is of a capital nature if the benefit of the purchased asset is applied to more than one accounting period.

\subsection{INTRODUCTION}

This article is a companion to "The Wade Case: An Analysis" written by the same authors and to be published in this journal. ${ }^{1}$ That article looks at the cases examined by their Honours in the Wade Case and similar cases related to the sale of livestock. It suggests that the findings of the Wade Case have been misinterpreted by the Australian Taxation Office (ATO) and that its view that ALL animals held in the business of primary production are trading stock may not be valid. This article argues that the revenue from the sale of stud, or breeding, animals should be taxed under the capital gains tax (CGT) provisions of the Income Tax Assessment Act 1997 (ITAA 1997) and not as income according to ordinary concepts.

\footnotetext{
* PhD (UNSW), M Com (Curtin), Adjunct Professor, Curtin Law School, Curtin University, Lex.Fullarton@curtin.edu.au. Lex Fullarton is also a former provincial tax practitioner.

** PhD (Law) (Melb), MTax (Hons) (Syd), Professor of Taxation Law, Curtin Law School, Curtin University, Dale.Pinto@cbs. curtin.edu.au.

1 A R Fullarton and D A M Pinto “The Wade Case: An Analysis” (2021) 27(2) NZJTLP (forthcoming).
} 
It examines the distinction between classifying expenditures by an enterprise as capital (assets purchased) or revenue (costs of operation). In particular, it looks at the taxation implications of accounting for livestock as trading stock purchased or bred for sale and those animals purchased or bred for breeding purposes. It considers the view of the ATO that ALL animals in a primary production business are considered trading stock, and the revenue from the sale is classified as income according to ordinary concepts and is therefore subject to income tax rates.

\section{Figure 1: A Young Heifer on the Rangelands of Western Australia ${ }^{2}$}

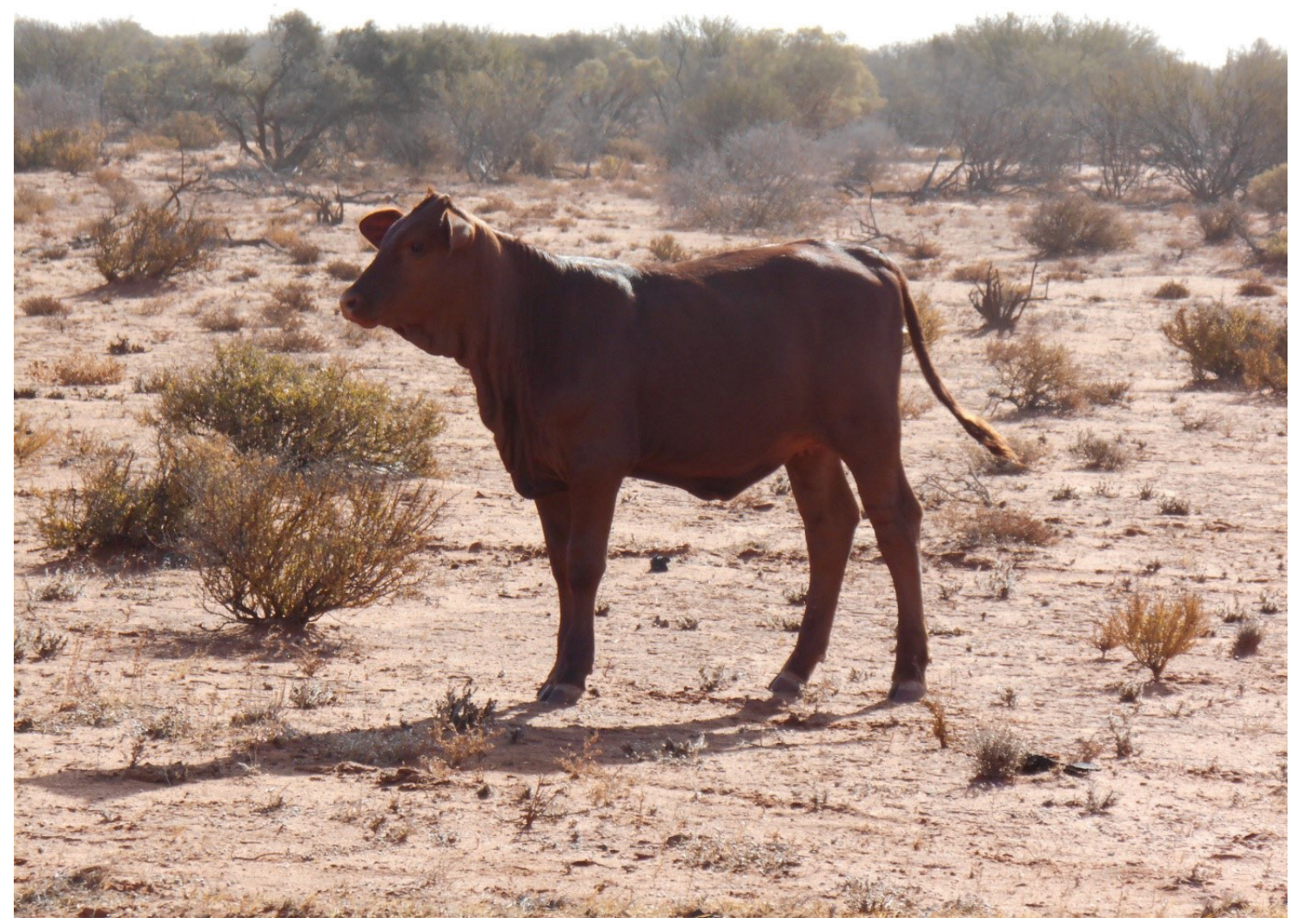

Figure 1 depicts a young shorthorn heifer. Is she destined to become a mother and therefore classified as a production animal (a capital asset), or produce (a revenue asset)? That issue is examined in this article as it argues that some animals should be classified as capital assets and therefore subject to the capital gains tax (CGT) provisions on their sale, instead of being classified as trading stock and subject to ordinary income tax rates.

To illustrate the distinction, the mustering crew at De Grey Station in Western Australia is shown in Figure 2. It is fair to assume that the inclusion of the horse-mounted stockmen and women indicates the horses are part of the station plant and not livestock for trading purposes.

2 Photograph of “Outback Heifer” taken by A R Fullarton (2020). 


\section{Figure 2: 'Meet the Crew' - the Mustering Team from De Grey Station'}

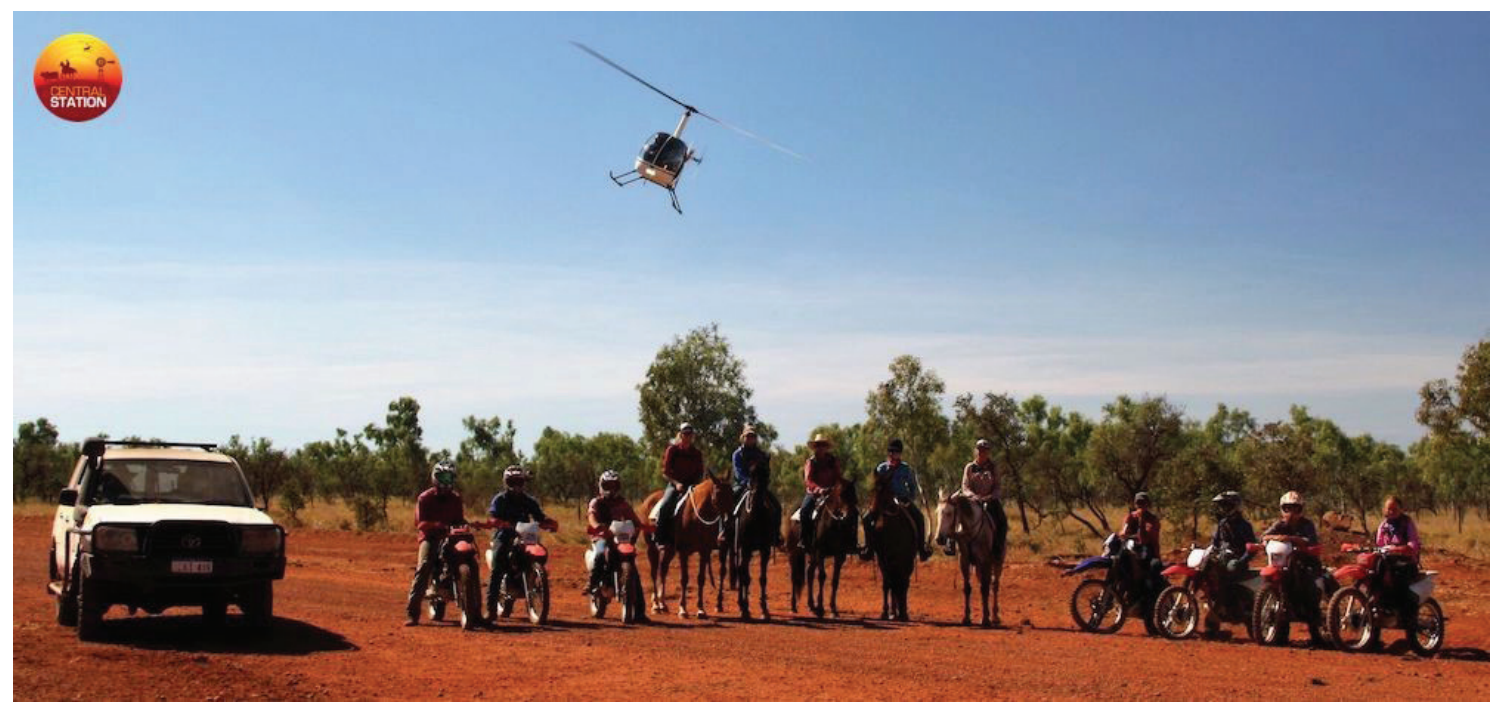

Another pastoral station manager stated that his horses and dogs were very expensive and highly trained. He said they had a key role in his mustering operations and could not be regarded as livestock in any way. 'To regard them as livestock is a lack of understanding of the pastoral industry." The illustrations are shown here to support the argument that ALL animals are not trading stock and that some should be regarded as capital assets.

This article argues that valuable stud animals are kept for breeding purposes and not for general sale as trading stock. Those animals are generally included in the sale of pastoral properties. Other than being sold with the properties, those animals are generally not sold as part of normal trading operations but may be sold at the end of their useful working life. Occasionally, sales of those animals may occur for other reasons such as droughts but not in the normal course of business.

To consider ALL animals as trading stock in Australia is not supported by the legislation. It is noted that the word ALL is not contained in s 995-1 of the ITAA 1997.

This article argues that the definition of livestock should not be extended to include animals held for their produce or used as working beasts. It suggests that the ATO's interpretation of livestock is too broad, and taxpayers are being deprived of CGT concessions and exemptions on the sale of pastoral properties in Australia. It is noted that the ATO view relies primarily on the findings in Federal Commissioner of Taxation v Wade (Wade Case)'. ${ }^{5}$ The Wade Case is not examined in this article but rather in detail in the companion article mentioned above.

This article deals with the accounting perspective. Therefore, to provide background and context, an overarching accounting pillar - the principle of ownership of a trading entity - is considered. The accounting

3 Photograph of "Meet the Crew", De Grey Station - Central Station, Central Station at $<$ www.centralstation.net.au/>. (Reproduced with permission of M Bettini of De Grey Station).

4 Telephone Conversation with Sean D'Arcy, owner and manager of Lyndon Station, Western Australia (Alexander Robert Fullarton, Curtin Law School, Curtin University, 24 December 2019).

5 Federal Commissioner of Taxation $v$ Wade (1951) 84 CLR 105. 
proprietorship equation is: Proprietorship (capital) is equal to Assets (what it owns) less Liabilities (what it owes) ( $\mathrm{P}=\mathrm{A}-\mathrm{L})$. It is understood that expenses reduce profits and therefore the value of a proprietorship, but the purchase of capital assets is a redistribution of profits and does not reduce but rather maintains the value of the proprietorship in a form other than cash.

Revenue generated from the sale of goods or services in the ordinary course of business generates profits that are subject to income tax according to ordinary concepts, ${ }^{6}$ but funds received from the sale of assets are a realisation of assets and do not generate a trading profit. Hence, any change in the value of the asset held by an entity on realisation will create a capital gain or loss and is treated differently from trading profits for taxation purposes. ${ }^{7}$

An example is provided below to illustrate and acknowledge that some receipts from some sources and activities fall outside the definition of ordinary income, ${ }^{8}$ and some receipts may not be considered income at all.

Revenue received by householders for electricity generated by small domestic solar photovoltaic (PV) systems is not considered as assessable income by the ATO. The ATO view is that those systems do not provide regular, reliable and realistic opportunities to profit from the arrangement, nor are they a "product of any employment, services rendered of business". ${ }^{9}$ Therefore, income received from the sale of electricity to the grid is considered to be of a private or domestic nature and not income according to ordinary concepts. ${ }^{10}$ It is also noted that the costs associated with the installation, depreciation and maintenance of the solar PV system are likewise not deductible. ${ }^{11}$ Albeit outside the scope of this discussion, the example illustrates that the view that ALL income is assessable income may not be accurate. Therefore, the word ALL should be applied with caution.

It is argued that the sale of breeding stock is the sale of business assets, especially when in conjunction with the sale of a pastoral property. Therefore, revenue received from the sale is not trading income according to ordinary concepts but rather a capital gain, and the funds should be taxed as a capital gain, not as ordinary income.

The argument is illustrated by a scenario that considers the sale of cattle in association with the sale of a pastoral lease. It looks at the beasts sold in conjunction with the sale of the pastoral business to consider:

- whether all animals on the property and sold as part of the transfer of the business should be considered as trading stock as part of the operation of the business, that is, revenue items and therefore taxed as income according to ordinary concepts; or

- whether animals on the property retained for breeding purposes and not generally for sale as part of the day-to-day operations of the property should be considered as capital assets and therefore taxed as capital gains and entitled to the capital gains tax discounts and s 152-D exemptions.

This article considers how the proceeds from the sale of a cattle station allocated to the animals retained for breeding purposes should be treated by describing the funds as a capital gain or loss for accounting

\footnotetext{
6 Income Tax Assessment Act 1936 (Cth), s 25; and Income Tax Assessment Act 1997 (Cth), s 6-5 (ITAA 1997).

7 ITAA 1997, pt 3-1, div 100.

8 ITAA 1997, s 6-1(5).

9 Australian Taxation Office Photovoltaic Solar System (Private Ruling, Authorisation Number 1012329040193, November 2011, edited 2019).

10 Australian Taxation Office, above n 9.

11 Australian Taxation Office, above n 9.
} 
and taxation purposes. It contends that the sale of pastoral and similar properties terminates the operation of the business. Therefore, the proceeds are not income according to ordinary concepts (normal trading) but rather are income from the sale of assets or from the liquidation and cessation of one business and the commencement of another. The authors argue that the component of those animals used as aids in manufacturing to produce goods - either by way of breeding trade animals or animal produce such as dairy products - be treated as capital assets, not trading stock, as currently considered by the ATO. ${ }^{12}$

The ATO view is supported by its reference to "the majority ruling of Dixon and Fullagar JJ in the High Court decision" of the Wade Case.$^{13}$ However, it is argued that some livestock should be considered as aids to manufacturing, or as breeding stock (s 385-100).

To provide background and context, the article briefly considers the purchase or creation of assets.

To illustrate the importance of taxation relief from the classification of stud animals as capital assets, div 118 of the ITAA 1997 acts to prevent the imposition of dual taxation on one transaction. Division 118 of the ITAA 1997 prescribes exemptions to CGT if income tax has been applied to that transaction. An in-depth examination of div 118 is beyond the scope of this article, but the relevant subsections are briefly outlined to illustrate how they might be applied to this research.

Consideration is specifically given to:

- s 118-20, which prevents CGT provisions from applying to revenue that is classified as assessable income for income tax purposes - that is, both income tax and CGT cannot be levied on the same revenue from the same transaction;

- s 118-24, which deals with capital gains arising from the application of capital allowances created under $\operatorname{div} 40$; and

- $\quad$ s 118-25, which prevents CGT provisions from applying to revenue received from the sale of trading stock - that is, for revenue generated from the sale of assets as in s 118-20 but specifically applied to trading stock.

To assist the reader, Figure 3 provides a decision matrix for the classification of goods into assets of a capital nature or products for resale to generate income or revenue. It shows the impact of segregating expenditures into revenue and capital and reveals the class of tax applicable to income according to ordinary concepts and gains from the sale of capital assets.

12 Letter from Alison Lendon, Deputy Commissioner of Taxation, to Alexander Robert Fullarton, 6 November 2019 (held by the author). The context is the ATO's view that all animals in a primary production business are considered as livestock within the definition of s 995-1 of the ITAA 1997. In the taxation advice letter provided to the author regarding the ATO's view of the classification of livestock in a primary production business, Lendon states, "The Commissioner [of Taxation] considers that the definition of livestock in section 995-1 of the Income Tax Assessment Act 1997 includes all animals in a primary production business."

13 Lendon, above n 12. 
Figure 3: Decision Matrix to Reveal the Tax Impact of Determining Purchases as Expenses or Assets

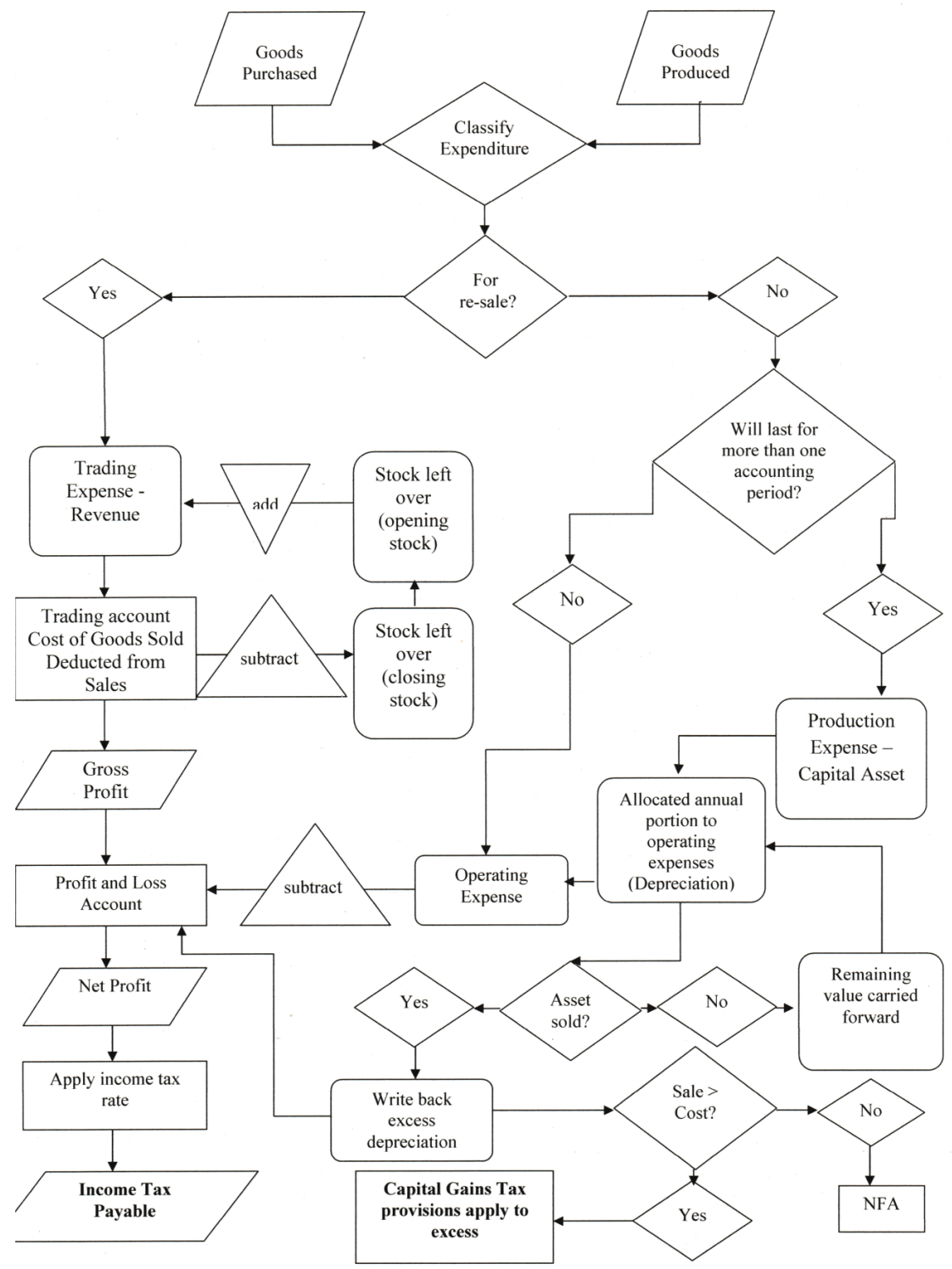

Kenny and Devos suggest that it is incumbent upon tax preparers and advisers to ensure capital gains tax (CGT) concessions are properly considered and reported. Hence, it is important for business owners, accountants and tax professionals to consider the classification of capital and revenue expenditure. It is also critical to consider the distinction between capital assets, which are subject to CGT, and transactions of a revenue nature, which are subject to income tax. 
They state:

Small business and/or their advisers will need to plan for the many [capital gains] tax concessions [available to small business entities in Australia]. Given the numerous concessions and the differing small business thresholds, this will impose significant costs for small business at or near any of the various thresholds. ${ }^{14}$

The principle of the case study supporting the findings of this article is that if the remaining cattle of any value are considered as breeding stock, then they are capital items. In such cases, CGT small business discounts apply, in particular the s 152-D exemption.

While the definition of livestock is contained within the provisions of the current income tax legislation (ITAA 1997), Lendon's advice ${ }^{15}$ relies on the 69 -year-old Wade Case. ${ }^{16}$ There are several explanations as to why the issue has not been challenged in nearly three-quarters of a century.

Generally, the CGT concessions apply only to individuals, and the bulk of pastoral leases are operated by corporate structures. Therefore, this issue may be considered extremely insignificant in the broader scope of the tax administrators and preparers in Australia. In addition, individuals disposing of their properties are generally elderly and retiring from working life. They may not be inclined to engage in protracted disputes with the ATO at that point in their lives and simply accept the higher-than-necessary tax burden as just another imposition on farmers, which they have endured all of their farming lives.

The regions where the activities are conducted are generally in the remote arid regions of Australia. The factor of remoteness may have influenced the lack of scrutiny of this issue in modern taxation policy and administration. In addition to being conducted in remote regions, sales of pastoral leases are comparatively rare when compared to the overall number of other transfers of land. ${ }^{17}$ In Western Australia, the average number of land transfers processed by the Western Australian Land Information Authority (Landgate) is about 5,700 per month. ${ }^{18}$ As shown in Figure 4, there were merely 361 transfers of pastoral leases in Western Australia over the 38 years from 1980 to 2018.

14 Paul Kenny and Ken Devos Australian Small Business Taxation (Butterworths, 2018) at 170.

15 Lendon, above $\mathrm{n} 12$.

16 (1951) 84 CLR 105.

17 Data provided by Government of Western Australia, Western Australian Land Information Authority ("Landgate") Pastoral Lease Sales from 1980 (2019), advised by email from Greg Walker, Service Manager, Business \& Government Solutions Strategy, Customers and Culture Landgate, to Alexander Robert Fullarton, 19 December 2019.

18 Government of Western Australia Business Activity (2019) available at <https://catalogue.data.wa.gov.au/>. 
Figure 4: Western Australian Pastoral Lease Transfers 1980-2018 ${ }^{19}$

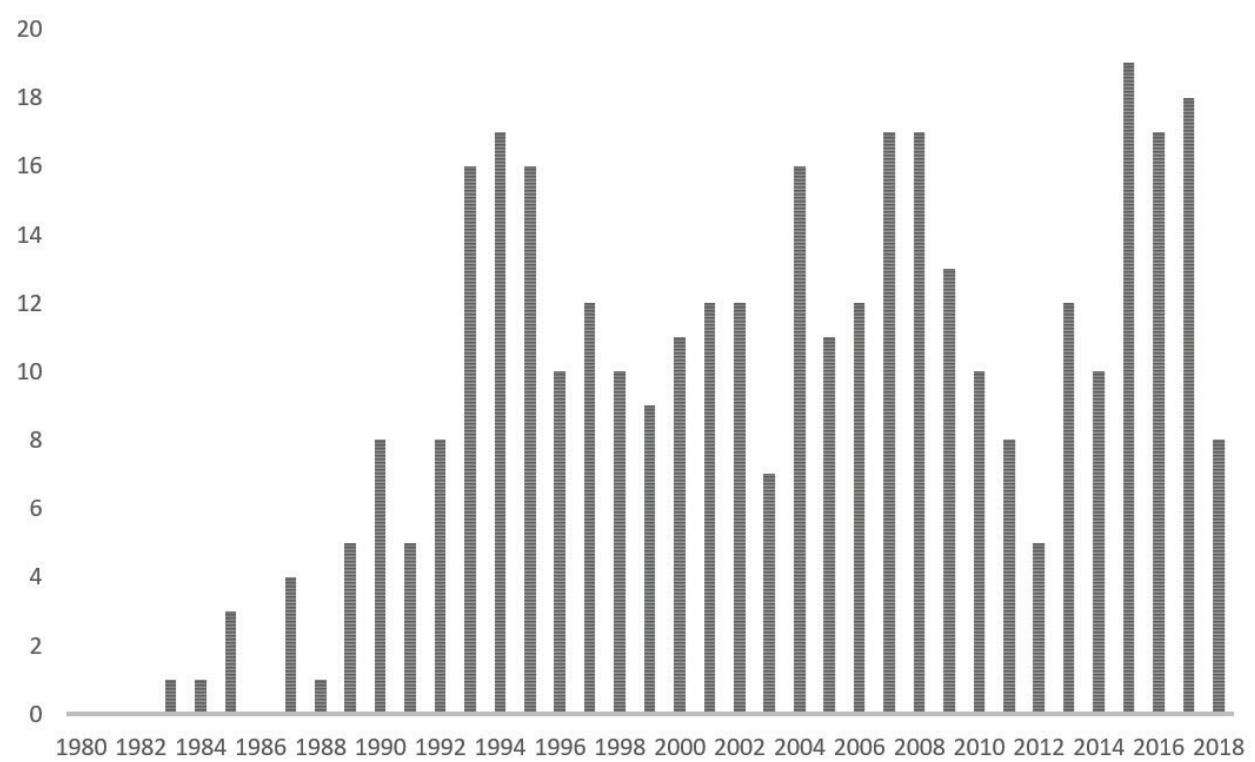

The modal average sale price is approximately A $\$ 1$ million. That is not a significant sum when compared to a home in an Australian city. In addition, just 10 sales per year is unlikely to raise concerns for taxation administrators.

Further, this article finds that tax preparers, pastoralists and their agents are somewhat divided in their opinions as to whether breeding animals, sold in conjunction with the transfer of pastoral properties, should be classified as capital or revenue assets. Those opinions are from persons involved in the modern pastoral industry and may differ from the view of the ATO, which is primarily based on a case that occurred in the dairy industry in Western Australia in the late 1940s. ${ }^{20}$

To cover the broad range of influencing factors identified, this article uses a mixed method research approach including:

- a series of interviews with stakeholders engaged in the operation and sale of pastoral properties in Western Australia who were asked to consider a hypothetical case study; and

- a quantitative survey using a Likert scale response system.

The following section outlines a hypothetical case study to provide background and context to the research. It outlines the case study put to the research participants for their consideration.

Although the scenario closely follows an actual event that is under scrutiny in this article, it is used to protect the privacy of the taxpayer concerned. In the close community of the pastoral region of Western Australia, some readers may identify the property, but all reasonable attempts have been made to disguise the actual persons involved. For ethical reasons, their permission has been obtained to publish redacted documents provided by them for the purposes of this research.

19 Government of Western Australia, Western Australian Land Information Authority, above n 17.

20 Federal Commissioner of Taxation v Wade (1951) 84 CLR 105. 


\subsection{HYPOTHETICAL CASE STUDY}

A woman works hard at her trade in a city and decides that one day she will own a cattle spread. The reality is that all she can afford is a very run-down station in a very remote and arid area. It is marginal, but with hard work, and some luck, it might return a modest income.

After about 10 years of much sweat and toil, and more than a few drops of blood in the 'bulldust', she is making a go of it. The harsh environment slowly gives way to her persistent husbandry. She has built up a reasonable stock of breeders, purchased a couple of good quality bulls and managed to turn off a reasonable number of cattle for market. She has passed 40 years of age and her 50th birthday is not far away - but look at this! She is the boss of her very own cattle empire (well, small village, really). She is far from the levels of Sidney Kidman, ${ }^{21}$ but she is living the dream, not the nightmare.

Disaster strikes! The persistent headaches, initially written off as due to lack of water and too much Fosters, ${ }^{22}$ are diagnosed as symptoms of terminal brain cancer. She has a year, maybe two left, according to the medical practitioner. She has lived a hard life and dies with dignity.

The property is sold, and her estate distributed. In preparation for the sale, she had mustered the property and every beast of commercial value was stripped from the property and sold. Only the breeding stock and animals too light to cover the costs of sale are turned back onto the grazing land.

The breeders had to be kept to provide marketable beasts to be included in the sale of the property, and the "weaners' ${ }^{23}$ would not return a reasonable profit at the point of sale of the property, even though they might well grow and be saleable in the future. The property is marketed, sold and settled within six weeks of the final muster.

Upon investigation, the executor of her will finds that the opinion of a number of public accountants is that while the proceeds of the sale of the property are generally considered a capital gain, the revenue from the sale of the remaining cattle is considered as the sale of trading stock and therefore liable to income tax at personal income tax rates. They point to s 995 of the ITAA 1997 to justify their opinion.

The executor argues that the small animals turned off are below commercial trade weight. While they will become valuable in the future, at the point of sale they were of no commercial value. He further argues that the breeding stock kept back for breeding purposes are capital items as they are used to manufacture products for sale in the same way that a lathe is used to make machine parts for sale.

The key to the case is the matter of capital gains tax exemptions applicable to an individual taxpayer on the sale of a business forced by medical factors. The executor argues that as the owner was under 55 years of age, quite clearly ill and subsequently died, the revenue from the disposal of the property, including the animals, thereupon is a capital gains tax event and permitted to claim the applicable capital gains tax exemptions.

The dominant theme of this research is to provide an understanding of the distinction between capital and revenue for accounting and taxation purposes. The focus of this study is the significance of the distinction

21 Sir Sidney Kidman, Australian Pastoralist, 1857-1935. Sidney Kidman left school at the age of 13 to become a cattleman in South Australia. He died, a cattle baron, in 1935 .

22 An Australian brand of beer favoured by the people of the pastoral regions of Australia.

23 Young animals recently weaned from their mothers as part of normal farming practice, particularly calves and lambs. 
between fixed and current assets because increases in the value of capital (capital gains) and profits from trading (revenue) are treated quite differently for taxation purposes.

Under Australian tax law, the sale of current assets is likely to fall under the income tax provisions of the ITAA 1997. Profits arising from the sale are taxed as income according to ordinary concepts, and income tax rates are imposed on them. In contrast, the sale of fixed assets is more likely to fall under the capital gains tax provisions of the ITAA 1997. Profits arising from the sale may be taxed as capital gains and may be taxed at a different rate and/or subject to a raft of discounts and exemptions.

It is noted here that this issue appears to apply only in Australia. Unlike the Australian legislation, the New Zealand legislation specifically includes ALL livestock as trading stock. ${ }^{24}$ The New Zealand Inland Revenue Department has issued a public ruling to that effect under s 91D of the Tax Administration Act $1994(\mathrm{NZ}) .{ }^{25}$

In Australia, income tax rates are substantially higher than capital gains tax rates. Prior to 1985, the imposition of tax on income from capital gains was very limited, ${ }^{26}$ and often, shifting profits from revenue income to capital gains receipts was used as a method of tax arbitrage. ${ }^{27}$

Section 3 considers the distinction between capital and revenue expenditures from both accounting and legal perspectives. It looks at the basic accounting conventions of proprietorships, or the owner's investment in an enterprise; capital purchases (long-term assets); and revenue purchases (trading expenses). It also reviews cases that have considered the distinction between proceeds from the sale of assets (capital gains) and revenue received from trading according to ordinary concepts - the sale of trading stock.

\subsection{LITERATURE REVIEW}

Expenditure falls into three broad categories: payments for the purchase of revenue assets for sale - trading stock; payments to provide for the operation of the enterprise on a day-to-day basis; and payments for long-term or capital assets that are used to produce goods or services for sale.

Prior to examining published literature to determine a definition of assets, capital and revenue, this article considers the following dictionary definitions. The definitions may not be legally binding in providing legal distinctions between the accounting concepts considered in this study, but they do form a useful basis for considering such distinctions.

The official dictionary for the Australian Guide to Legal Citation, ${ }^{28}$ the Macquarie Dictionary, defines assets as "commerce resources of a person or business consisting of such items as real property, machinery, inventories, notes, securities, cash etc". ${ }^{29}$ Capital is defined as "the wealth, whether in money or property, owned or used in business by an individual, firm, etc; an accumulated stock of such wealth; [and] any

24 Income Tax Act 2007 (NZ), s YA 1: (definition of 'trading stock').

25 New Zealand Inland Revenue Department, Tax Technical "Income Tax - Timing of Disposal and Derivation of Income from Trading Stock” BR PUB 14/08 (30 September 2014) available at <www.taxtechnical.ird.govt.nz/>.

26 "Until 19 September 1985 Australia had no capital gains tax. There were, however, two important provisions of the ITAA 1936 that equated capital gains tax with income $-\mathrm{s} 25 \mathrm{~A}$ and s 26AAA, which treated profits on the sale of property purchased and sold within 12 months as assessable income. Despite those two sections and some others throughout ITAA 1936 that assessed amounts that would not otherwise be income, as a basic principle, prior to 19 September 1985, capital amounts were not taxed." Deutsch and others, Australian Tax Handbook 2000 (ATP, 2000) at 242.

27 McClelland v Federal Commissioner of Taxation [1970] UKPCHCA 1; (1970) 120 CLR 487.

28 Melbourne University Law Review Australian Guide to Legal Citation (4th ed, 2018).

29 C Yallop and others (eds) Macquarie Concise Dictionary (4th ed, 2006) 'assets' (def 1). 
form of wealth used, or capable of being used in the production of more wealth" ${ }^{30}$ It defines revenue as "the collective items or amounts of income of a person, a state, etc. [or] return or yield from any kind of property". 31

The Oxford Dictionary defines assets as "any property or effects available to meet the debts of a testator, debtor or company whether sufficient or not". ${ }^{32}$ It defines capital as "the stock with which a company or person enters into business; the total sum of shareholders' contributions in a joint-stock company; accumulated wealth, esp, as used in further production". ${ }^{33}$ Revenue is defined as "income spec from property, possessions, or investment, esp, of an extensive kind". ${ }^{34}$

Significant to this study is the Yorston, Smyth and Brown definition of stock-in-trade as: ${ }^{35}$

the aggregate of those items of tangible property which are:

1. held for sale in the ordinary course of business, or

2. in the process of production for such sale, or

3. to be currently consumed in the production of goods or services to be available for sale.

It is inferred that the distinction between fixed and current assets is the time taken to convert the asset to cash. In particular, for taxation purposes, that definition of duration is significant for the distinction between an asset and a revenue expense. A fixed asset may take some time and cost to convert to cash and have a significant impact on the operations of an enterprise. In contrast, a current asset is either cash or is readily converted to cash within a short time. In the main, the sale of current assets is part of the normal operations of an enterprise, while the sale of a fixed asset is not.

However, the 1975 Asprey Report noted that all livestock are considered as trading stock. It suggested that changes in the closing value of livestock would have an impact on income for taxation purposes. ${ }^{36}$ The Asprey Report states: $:^{37}$

All livestock in a business of primary production are treated by the Act as trading stock even though some animals are not acquired for the purpose of sale.

However, it further considered that some livestock, such as stud stock, could form part of the assets of a business along with the plant. It states: ${ }^{38}$

Although animals not acquired for the purpose of sale (for example, stud stock) could be regarded as more akin to plant than trading stock, there is no provision in the Act for writing off annual amounts of depreciation from their cost. $^{39}$

For this purpose, the provision of capital and property to a partnership would not only include funds and assets overtly contributed as partnership capital. It would also extend to property, including loan moneys made available

30 Yallop and others (eds), above n 29, 'capital' (def 3).

31 Yallop and others (eds), above n 29, 'revenue' (def 2).

32 Angus Stevenson (ed), Shorter Oxford English Dictionary: On Historical Principles (6th ed, 2007) 'asset' (def 2).

33 Stevenson (ed), above n 32, 'capital' (def B2).

34 Stevenson (ed), above n 32, 'revenue' (def 2).

35 K Yorston, E B Smyth and S R Brown, Advanced Accounting (Law Book, 1978) at12. This definition is based on the definition of 'Inventory' as contained in Chapter 4, Accounting Research Bulletin, No 43, 1953 of the American Institute of Accountants.

36 Yorston, Smyth and Brown, above n 36, at 105-106.

37 Taxation Review Committee, Full Report (Parliamentary Paper No 136, January 1975) (Asprey Report) at 99.

38 Asprey Report, above n 37, at 150.

39 Asprey Report, above n 37, at 283. 
for use in the partnership business without recompense or on favourable terms, and any other benefit given or granted to the partnership by one or more partners but not by all partners according to their shares, such as land, livestock, plant, goodwill, etc. owned by one partner but used by the partnership without realistic recompense.

Therefore, it is argued that the Asprey Report is inconclusive in its findings as to the classification of livestock as current assets (revenue items) or capital assets (capital items).

From the Asprey Report, it appears that if stud stock were to be depreciated, then they may well be considered as plant. The report also points to the influence of accounting treatment for distributing the capital cost over several accounting periods in helping to determine if livestock kept for stud purposes should be revenue or capital items.

Bazley and others support their definition of assets by quoting the Statement of Accounting Concepts (SAC 4): ${ }^{40}$

"Assets are future economic benefits controlled by the entity as a result of past transactions or other past events." 41

Revenue is defined by Bazley and others as: ${ }^{42}$

inflows or other enhancements, or savings in outflows, of future economic benefits in the form of increases in assets or reductions in liabilities of the entity, other than those relating to contributions by owners, that result in an increase in equity during the reporting period (SAC 4, para 111).

The distinction between assets and revenue as defined by Bazley and others is that assets are a means of creating economic benefits, and revenue is the economic benefit created by the asset. The Accounting Handbook 2001 also prescribes the definitions set out in SAC 4 for use by members of CPA Australia and the Institute of Chartered Accountants in Australia. ${ }^{43}$

The historical perspective of the recognition of property, plant and equipment changed in Australia with the introduction of the Australian Accounting Standard AASB 116 in $2005 .{ }^{44}$ The standard has been amended since that time and its application as of January 2020 is as follows: ${ }^{45}$

This compiled Standard applies to annual periods beginning on or after 1 January 2019 but before 1 January 2021.

Earlier application is permitted for annual periods beginning on or after 1 January 2014 but before 1 January 2019.

It incorporates relevant amendments made up to and including 9 December 2016.

Broader discussion of AASB 116 is beyond the scope of this article, but it is noted that AASB 116 was enacted in compliance with Australia's international obligations imposed in accordance with the International Accounting Standard (IAS) 16 "Presentation of Financial Statements", as issued and amended by the International Accounting Standards Board (IASB).

40 The Public Sector Accounting Standards Board of the Australian Accounting Research Foundation and the Australian Accounting Standards Board "Statement of Accounting Concepts SAC 4 (3/95) Definition and Recognition of the Elements of Financial Statements" (1995) available at <www.aasb.gov.au>.

41 M Bazley et al Contemporary Accounting: A Conceptual Approach (3rd ed, Nelson Australia, 1999) at 49; see also G Carnegie and others Financial Accounting: Financial and Organisational Decision Making (McGraw-Hill,1999) at 66.

42 Bazley, above $\mathrm{n} 41$, at 51.

43 C Parker (ed) Accounting Handbook 2001: Volume 1 of the Accounting and Auditing Handbook 2001 (Prentice Hall, 2001) at 35; see also M A Sims and R C Clift Australian Corporate Accounting: The Formulation, Expansion and Dissolution of Companies (McGraw-Hill, 2001) at 74, 173; C Deegan Financial Accounting Theory (McGraw-Hill, 2001) at 134.

44 Australian Accounting Standards Board Accounting Standards AASB 116 (2019) available at <www.aasb.gov.au/>.

45 Australian Accounting Standards Board, above n 44. 
Of relevance is the objective of AASB 116, which is: ${ }^{46}$

to prescribe the accounting treatment for property, plant and equipment so that users of the financial statements can discern information about an entity's investment in its property, plant and equipment and the changes in such investment. The principal issues in accounting for property, plant and equipment are the recognition of the assets, the determination of their carrying amounts and the depreciation charges and impairment losses to be recognised in relation to them.

It states: ${ }^{47}$

Property, plant and equipment are tangible items that:

(a) are held for use in the production or supply of goods or services, for rental to others, or for administrative purposes; and

(b) are expected to be used during more than one period.

AASB 116 defines plant and equipment as tangible items for use for more than one [accounting] period (year). It is suggested that retaining an animal for production of saleable assets for a number of years gives substance to the argument that animals retained for production purposes are plant and therefore a capital asset, rather than stock held for trading purposes.

AASB 116 appears to settle the argument from an accounting perspective. However, it does not apply to: ${ }^{48}$

(b) biological assets related to agricultural activity other than bearer plants (see AASB 141 "Agriculture").

Therefore, this article examines the accounting compliance requirements set out in Accounting Standard AASB 141 "Agriculture". ${ }^{49}$ It is noted that AASB 141 was enacted in compliance with Australia's international obligations imposed in accordance with International Accounting Standard (IAS) 14 "Agriculture".

The examination seeks to establish the impact of AASB 141 on the classification of biological assets as current (revenue) or non-current (capital) assets. Further, it seeks to clarify whether AASB 116 is to be totally ignored when accounting for biological assets. As with the examination of AASB 116, this examination is restricted to the elements that are the focus of this article and is not intended to be an in-depth examination of the accounting standard.

Significantly, AASB 141 defines a biological asset as a living animal or plant. ${ }^{50}$ Dairy cattle for the production of milk, the focus of the Wade Case, are provided as an example of biological assets. ${ }^{51}$ Hence, AASB 141 applies to the accounting treatment of the cattle held for breeding purposes.

AASB 141 gives examples to illustrate the distinction between 'consumable biological assets' as being agricultural assets which: ${ }^{52}$

46 Australian Accounting Standards Board, above n 44.

47 Australian Accounting Standards Board, above n 44, at [7].

48 Australian Accounting Standards Board, above n 44, at [3(b)].

49 Australian Accounting Standards Board Accounting Standards AASB 141 (2019) available at <www.aasb.gov.au/>.

50 Australian Accounting Standards Board, above n 49, at [5].

51 Australian Accounting Standards Board, above n 49, at [4].

52 Australian Accounting Standards Board, above n 49, at [44]. 
are those that are to be harvested as agricultural produce or sold as biological assets. Examples of consumable biological assets are livestock intended for the production of meat, livestock held for sale, fish in farms, crops such as maize and wheat, produce on a bearer plant and trees being grown for lumber.

and 'bearer biological assets' as agricultural assets which: ${ }^{.3}$

are those other than consumable biological assets; for example, livestock from which milk is produced and fruit trees from which fruit is harvested. Bearer biological assets are not agricultural produce but, rather, are held to bear produce.

It is argued that animals held for breeding livestock for sale are bearer biological assets (capital) and not consumable biological assets (revenue), as are the dairy cattle described in AASB 141. Of relevance to this article is that the standard specifically refers to 'non-current' biological assets and how they are to be treated once they meet the criteria to be classified as being held for sale and therefore become held as current assets. ${ }^{54}$

AASB 141 details how biological assets are to be valued and reported for financial accounting disclosure purposes. Chiefly, it acknowledges the vagaries of market values of biological assets as a consequence of a range of natural and economic influences on their value from time to time.

It appears the key philosophy of AASB 141 is that historical cost valuations, generally used in accounting conventions, and in particular AASB 116, are inappropriate for a true and accurate disclosure of value when accounting for biological assets. It specifically acknowledges variations in value due to: ${ }^{55}$

biological transformation results in the following types of outcomes:

(a) asset changes through (i) growth (an increase in quantity or improvement in quality of an animal or plant), (ii) degeneration (a decrease in the quantity or deterioration in quality of an animal or plant), or (iii) procreation (creation of additional living animals or plants); or

(b) production of agricultural produce such as latex, tea leaf, wool, and milk.

Further, it does not function as an alternative accounting standard to AASB 116 but rather as a complement to it and other standards: ${ }^{56}$

In determining cost, accumulated depreciation and accumulated impairment losses, an entity considers AASB 102, AASB 116 and AASB 136 Impairment of Assets.

It is therefore appropriate that the Australian Accounting Standards are a valid support for the argument of this article that livestock held for breeding purposes for at least more than one accounting period are capital assets and not stock in trade, that is, revenue items.

Fischer and Marsh ${ }^{57}$ examined the generally accepted accounting principles (GAAP) existing in the United States at that time to explore the impact of the adoption of the international accounting guidance for agricultural activities. They found that "there [were] systematic differences between the US generally accepted accounting principles and International accounting and reporting for agricultural assets and products". ${ }^{58}$

53 Australian Accounting Standards Board, above n 49, at.

54 Australian Accounting Standards Board, above n 49, at [30].

55 Australian Accounting Standards Board, above n 49, at [7].

56 Australian Accounting Standards Board, above n 49, at [33].

57 M Fischer and T Marsh "Biological Assets: Financial Recognition and Reporting Using US and International Accounting Guidance" (2013) 13(2) Journal of Accounting and Finance 57.

58 Fisher and March, above n 57, at 68. 
They also found: ${ }^{59}$

that international and US agricultural accounting recognition and reporting guidance results in dissimilar reporting due to guidance interpretation. IAS 41 is an effort to improve comparability of agricultural companies' financial statement. However, valuation variances and definition differences including the requirement to change the agricultural asset recognition method from historical cost to fair value continue to be the basis of major reporting differences.

They point to the complexities of market vagaries regarding developing animals. They consider the example of the growth of a newborn animal. They state: ${ }^{60}$

the assigned value using LCM [lower of cost or market] value to a newborn would be zero. For the first 3 to 10 months of an infant's life cycle, the newborn only requires the mother's milk and the only cost allocated to the newborn would only be the boarding. This presents a valuation issue as GAAP Codification 905 guidance recognizes 3-month-old calves at zero on the balance sheet when in the Western US cattle producing area 3 to 6-month-old calves have a fair market value of $\$ 200$ to $\$ 300$ or higher.

They considered the dilemma of breeding and production animals reaching maturity and the base value for depreciation. Their example suggests that the cost of a two-year-old heifer could reasonably be established, but what if the livestock market at the point of annual valuation is less than that cost and the market range is between US\$600 and US\$1,300 ${ }^{61}$

An issue that could also be considered is the point in time at which the animal is classified as a breeding or production animal and no longer trading stock. Cattle under the mature age of 15 months could not be considered breeding stock, but what if the cattle beast is 24 months of age?

By determining that an animal that is held for more than one accounting period (year) becomes a breeding or production animal or by defining ALL livestock as trading stock, the dilemma of annual valuations and classification of breeding or production stock and stock for resale is avoided. However, it does not comply with the accounting compliance provisions of AASB 141. The adoption of AASB 141 creates a tax effect accounting reconciliation matter for tax preparers.

A further consideration of this article is that a finding that compensation paid to Wade in 1951 was of a capital nature may have exempted those monies from taxation entirely. However, capital gains tax was introduced in 1985, and div 108 of the ITAA 1997 now applies to the imposition of capital gains tax on capital gains and losses from the acquisition and disposal of capital assets.

It is noted that the provisions of s 118-20 act to prevent the imposition of both income tax and capital gains tax on the same transaction. The levy of tax on gains or losses from the sale of livestock held for breeding purposes is not disputed but rather the type of tax levied - income tax or capital gains tax.

This review looked at the interpretation of the Asprey Report which considered ALL livestock as trading stock but then stated that some livestock, such as stud stock, could form part of the assets of a business along with plant.

It also considered that a consistent criterion for defining current and non-current assets is the ownership over several accounting periods (years). That stud stock are held for many seasons (years) lends weight to

59 Fischer and Marsh, above n 57, at 68.

60 Fischer and Marsh, above n 57, at 59.

61 Fischer and Marsh, above n 57, at 59. 
the argument that stud stock are more likely to be non-current assets than stock in trade held for the singular purpose of resale for a profit.

The following section details the design of the research paradigm conducted to substantiate its findings and conclusions.

\subsection{RESEARCH DESIGN AND CONDUCT}

A combination of quantitative and qualitative research approaches was adopted to support the findings of this article. The mixed methods or multi-method research approach ${ }^{62}$ was adopted to support the narrative.

Yin suggests that whilst quantitative surveys are a commonly used method for collecting and analysing empirical evidence, there is a need to engage in qualitative case studies to address the questions of 'how' and 'why'. ${ }^{63} \mathrm{He}$ indicates that the case study strategy has distinct advantages, particularly where the research is focussed on the question of why. ${ }^{64}$

Other researchers also support the use of a mixed methods approach. In assessing the validity of qualitative interviews, Merriam ${ }^{65}$ argues that whilst quantitative research exposes the facts and clearly illustrates what is happening, it cannot discover the 'reality' itself. ${ }^{66}$ Further, John Sydenstricker-Neto points out weaknesses in the singular use of statistical analysis, or quantitative research, and suggests that: "[a]dding qualitative flesh to the quantitative bones is a good strategy to overcoming some of these problems". ${ }^{67}$

The article seeks not only to assess what is understood by tax preparers to be the appropriate classification of animals in accounting terms but also why they have established that understanding.

For the purposes of consistency, both the quantitative survey and qualitative study consider the same hypothetical scenario which was presented to both survey participants and case study interviewees. Although it is based on a hypothetical scenario, this case study could also be applied to almost any rural property or farm carrying livestock for commercial purposes in Australia.

The study used a Likert scale from one to five, ranging from 'all animals are breeding stock (capital)' to 'all animals are trading stock (revenue)', or combinations of both in between to answer the research question: "On the sale of a rural business (farm or pastoral lease) involving livestock, are all animals (cattle, sheep, goats and the like) considered as trading stock and therefore revenue items? Alternatively, are some, or all, animals breeding stock and therefore subject to capital gains tax provisions and exemptions?"

The quantitative survey conducted as grounding for this research gives an indicator of what is understood as the 'correct' interpretation of the classification of livestock. It also indicated the dominant interpretation by the broader population of tax preparers.

62 M B Miles and A M Huberman Qualitative Data Analysis (2nd ed, Sage, 1994) at 2; J Corbin and A Strauss Basics of Qualitative Research (3rd ed, Sage, 2008) at 25; J Elliott Using Narrative in Social Research: Qualitative and Quantitative Approaches (Sage, 2005) at 157-159; M Crotty The Foundations of Social Research: Meaning and Perspective in the Research Process (Sage, 2003) at 15; J W Creswell Research Design; Qualitative, Quantitative and Mixed Methods Approaches (2nd ed, Sage, 2003) at 17; M McKerchar Design and Conduct of Research in Tax, Law and Accounting (Thomson Reuters, 2010).

63 R K Yin Case Study Research: Design and Methods (3rd ed, Sage, 2003) at 6.

64 Yin, above n 63. Yin categorises research questions as 'who', 'what', 'where', 'how' and 'why'.

65 S B Merriam Qualitative Research and Case Study Applications in Education (2nd ed, Jossey-Bass, 1998).

66 Merriam, above n 65, at 202.

67 J Sydenstricker-Neto "Research Design and Mixed-Method Approach: A Hands-on Experience" (1997) available at <www. socialresearchmethods.net/>. 
This article then looked at the underlying question of why they established that understanding. A number of interviews were conducted with persons engaged in the sale of Outback pastoral leases in Western Australia. They were interviewed to assess what they believe to be an appropriate approach to classifying animals for accounting and taxation purposes. They were asked their opinions as to whether animals could be considered as stock for breeding, or stud, and therefore capital items, or as livestock for sale and therefore revenue items.

The scope of interviewees consisted of:

- a rural-based accountant/tax preparer from northern Victoria;

- an urban-based accountant/tax preparer from the city of Perth in Western Australia;

- a purchaser of a pastoral property in the Northwest of Western Australia;

- the executor of a vendor of a pastoral property in the Northwest of Western Australia;

- a licensed real estate and business agent engaged in the sale of rural and pastoral properties in Western Australia; and

- a person engaged in the pastoral industry in the Northwest of Western Australia.

It was considered that those interviewees covered a broad scope of experience and opinions from a range of relevant perspectives. They were interviewed to provide insights into how those engaged in the pastoral industry view the distinction between livestock raised for sale as trading stock and those animals kept for breeding or stud stock to maintain their production herds.

To support the qualitative study, an ATO ruling was sought on the hypothetical case study, and a taxpayer also provided the contract of sale and income tax return for the purpose of analysis of the sale of a property in April 2017.

Further, in its advice, the ATO stated that it relied on the findings in the Wade Case to form the opinion that "[t]he Commissioner considers that the definition of livestock in section 995-1 of the Income Tax Assessment Act 1997 includes all animals in a primary production business". Hence, the findings in the Wade Case are also examined to support or refute that opinion and to increase confidence in the conclusions of this article.

Further, in its advice, the ATO stated that it relied on the findings in the Wade Case to form the opinion that "[t]he Commissioner considers that the definition of livestock in section 995-1 of the Income Tax Assessment Act 1997 includes all animals in a primary production business". ${ }^{68}$ Hence, the findings in the Wade Case are also examined to support or refute that opinion and to increase confidence in the conclusions of this article.

The article compares the findings of the quantitative and qualitative research to conclude whether the prevailing interpretation of the ATO and Australian tax preparers is appropriate. It also quantifies the applicable taxation burden of the alternative classifications - are the animals transferred on the sale of a rural property 'mother' (capital) or 'meat' (revenue), or a combination of both?

68 Lendon, above n 12. 


\subsection{RESEARCH ANALYSIS AND OUTCOMES}

\subsection{Case Study Analysis - Tax Practitioner Survey}

While there are 42,501 individual tax practitioners registered as tax agents as of October $2019,{ }^{69}$ the Tax Practitioners Board was unable to identify precisely how many agents are active or the number of practices that exist. It further advised that "[m]any agents can work for other entities and also have a practice themselves". ${ }^{70}$ Therefore, the total population of tax agencies in public practice is unknown.

The Institute of Public Accountants (IPA) advised that it had 3,060 active public practitioners in Australia. ${ }^{71}$ While the IPA is a significant professional accounting body in Australia, its membership is somewhat less than that of the Chartered Accountants Australia and New Zealand. Nonetheless, the population of 3,000 active practitioners out of a total membership of about 35,000 indicates that the number of active tax practitioners in Australia may be less than 10,000.

However, as this research focuses on rural properties, and given that the volume of sales of pastoral leases in Western Australia was only 361 over 38 years, compared to an estimated 2.6 million land transfers, the population of tax preparers who have encountered the sale of pastoral leases in Australia is likely to be comparatively few.

Further, the survey focussed on rural practitioners because it was assumed that they would be more likely to experience pastoral land sales than urban practitioners. As the total population of tax practitioners who have compiled income tax returns for taxpayers who have transferred pastoral leases cannot be accurately determined, assumptions have been made using the above comparatives.

If the total population of individual tax practitioners is somewhat less than 42,501 and the ratio of pastoral sales to total land transfers is 0.0139 per cent (based on the Western Australia statistics), then only six tax preparers would be expected to have experience with the conduct of pastoral land sales in Western Australia. Only 12 practising CPA public practitioners could be found beyond the Adelaide metropolitan area in South Australia. However, two urban-based practices were found that had rural clients.

Intuitively, the total population of rural-based tax preparers is likely to be extremely small compared to the total population of registered tax practitioners.

A quantitative survey of 96 public tax practitioners of the Institute of Public Accountants was conducted. Three attempts were made to engage those accounting practices by electronic mail, and direct contact by staff of the Institute was conducted over a period of 12 months. At the conclusion of the survey, 14 responses were received. A further telephone survey of 14 South Australian CPAs was conducted, from which five responses were obtained.

Table 1 shows the number of responses in each category from 1 'all animals are breeding stock (capital)' to 5 'all animals are trading stock (revenue)' and the ratios in between $(25 / 75 ; 50 / 50$; and 25/75 of breeding to trade stock).

69 Tax Practitioners' Board, "Search the Register" (2019) available at <www.tpb.gov.au>.

70 Email from Client Support Team, Tax Practitioners' Board, to Alexander Fullarton, 28 November 2019.

71 Email from Laura Baynes, Institute of Public Accountants to Alexander Fullarton, 21 October 2019. 
Table 1: Table of Survey Responses: Mother or Meat Survey of Tax Preparers ${ }^{72}$

\begin{tabular}{|l|c|c|c|c|c|c|c|}
\hline Category & 1 & 2 & 3 & 4 & 5 & total & population \\
\hline $\begin{array}{l}\text { Aust IPA } \\
\text { responses }\end{array}$ & 0 & 1 & 3 & 4 & 6 & 14 & 96 \\
\hline $\begin{array}{l}\text { SA CPA } \\
\text { responses }\end{array}$ & 1 & 0 & 1 & 0 & 3 & 5 & 14 \\
\hline sub-total & 1 & 1 & 4 & 4 & 9 & 19 & 110 \\
\hline percentage & 5.26 & 5.26 & 21.05 & 21.05 & 47.37 & 100 & \\
\hline
\end{tabular}

By considering the Null Hypothesis 'Not ALL Australian tax preparers agree with the ATO view that ALL animals in a primary production business are livestock for trading purposes', from the raw data, the number of those who do consider ALL animals livestock (category 5) is compared to those who do not (categories 1-4). A chi-square test of 0.0219873 is obtained using the Excel spreadsheet program. That indicates the survey is statistically significant.

The survey found that only one of the respondents considered all of the animals in the proposed hypothetical scenario as capital, despite only some of those animals being held for breeding purposes and others, such as calves, being of no commercial value. Yet, less than half of the respondents determined that they were ALL trade stock, with 52.6 per cent favouring the concept that at least some of the animals should be classified as breeding stock to varying degrees.

The scale 1 respondent detailed a reasonably complex accounting and registration system that should be maintained to ensure the numbers and values of breeding stock were kept segregated from the trading stock. She suggested that the animals considered to be of no commercial value at the point of transfer be recorded in the Livestock Trading Account by number at no monetary value. At the point of sale of those animals sometime in the future when they had reached trade weight and therefore were of commercial value, then the profit would be accurately disclosed in the Livestock Trading Account.

A comment from one of the respondents who scored 3 on the scale (either breeding stock or trading stock) was:

Stock that is purchased for resale is trading stock and would be treated as such if the farm or lease was sold. Stock that is not purchased for resale (breeding) should be treated as an active business asset and depreciated the same as any other asset. There are current rulings that deal with race horses and other livestock. If the breeding stock is sold in the process of the farm sale, the disposal can only be on income account. The same condition applies if you were to sell general plant and equipment; this will never be on capital account. The accounting profit being the difference between the written down value of the asset and the consideration received.

It appears the respondent is accounting for a profit or loss on the sale of breeding stock as an extraordinary profit or loss in the revenue statement, and it is income according to ordinary concepts, rather than a capital loss or gain for CGT purposes.

Another scale 3 respondent commented:

The tax treatment would greatly depend on numbers. We would consider writing off lame animals, those kept for breeding, treat as breeding stock and those left treat as stock not kept for breeding.

72 The estimate of the total population of rural tax preparers was established from the postcodes declared to be the area of operations of IPA and CPA members published on the Institute websites. 
A scale 4 respondent commented:

60 per cent IT and 40 per cent CGT provisions would seem fair for properties in remote Australia (shrublands). An actual split/classification for other regions.

Interestingly, the respondent added:

From my experience, most 'farmers' don't pay very much tax at all. The only time they really contribute to the revenue of Australia is when they finally sell up and the livestock is treated as trading stock (IT provisions). Maybe treating 'livestock' as an active asset but no discount would be a fair compromise.

This respondent appears to have a value judgment that farmers receive favouritism from the taxation system and do not pay their 'fair share' of tax. The discussion of tax minimisation schemes is beyond the scope of this article. For an in-depth analysis of taxpayer attitudes toward tax minimisation, Fullarton investigated taxpayer engagement in the mass-marketed tax avoidance schemes of the 1990s. ${ }^{73}$

A scale 5 respondent adopted a practical philosophy:

I can see possibilities though think it would have to stay as trading stock for reasons:

1) Too hard to police separation of trading stock from breeding stock.

2) Breeding stock losses from deaths or any other reason would logically be a capital loss and in most (primary producer) cases would be a nuisance as they generally have a low incidence of use for capital losses (that can only offset against cap gains).

Another scale 5 respondent also reflected the practical nature of animal classification. He considered the matter simply:

It should be 3 but usually it is too late for the accountant to have any input [in the allocation of funds which make up the total price the sale of the property].

The final scale 5 respondent who commented acknowledged there could be CGT provisions if breeding stock were separated, but they are not. Therefore, considering all animals as trading stock provides for the "equitable cost base for the purchaser's livestock profit and loss business [account]".

Despite inaccuracies that may arise from a survey population of just 19 respondents, the survey indicates that tax preparers are much divided in their perspectives as to the classification of livestock. Nearly all, including those who hold the opinion that ALL livestock are trading stock, acknowledged that breeding stock should be considered separately as active assets, even if the accounts were not kept in that fashion.

It is suggested that although many of the animals are not considered separately as breeding stock and therefore subject to CGT and related concessions, that decision is influenced by other factors.

Some of those other factors include the attitude of one respondent that considering ALL livestock as trading stock would be a method by which "farmers finally pay their 'fair share' of tax". That was justified from a social justice point of view rather than lawful or economic equity, even if it arose from inaccurate accounting treatment on the sale of their properties.

A view held by a respondent implied that farmers 'fiddled the system' and did not pay their fair share of tax throughout their farming life, so it is fair that they overpay their tax in the end. ${ }^{74}$ Further discussion as to

73 A R Fullarton Heat, Dust and Taxes: A Story of Tax Schemes in Australia's Outback (Ibidem Verlag, 2014).

74 Survey Respondent. 
the equity or fairness of tax liability of farmers arising from the classification of livestock as trading stock is beyond the scope of this research.

To add qualitative 'meat' to the quantitative 'bones"75 of the survey, the article now examines the opinions of other stakeholders in the sale of pastoral properties, including two tax preparers, to boost reader confidence in the findings of this research.

\subsection{Case Study Analysis - Stakeholder Interviews}

Seven persons contributed to the stakeholder interviews, including a vendor, their respective agents and a purchaser of a pastoral property in Western Australia.

The study also included long-term pastoralists. They were descendants of three generations of a family engaged in the pastoral industry and have no intention of selling in the foreseeable future, if at all, but rather passing the ownership on to the following family generations. Their opinion was sought as independent support for how transactions relating to herds were managed and classified on modern pastoral properties, at least in Western Australia.

The analysis will follow the pattern of involvement of stakeholders in relation to owning and operating a pastoral lease through the process of selling the property to the new owner.

The stakeholders interviewed by occupation were:

- two pastoralists from the Gascoyne region of Western Australia;

- a vendor of a pastoral property;

- a pastoral lease broker;

- a purchaser of a pastoral property;

- a rural public accountant/tax preparer from northern Victoria; and

- an urban public accountant/tax preparer from Perth in Western Australia.

The study found that all of the interviewees stated that they were familiar with the sale of pastoral properties. However, the number of transactions that they had been involved in was very limited. The exception to that situation was the professional licensed real estate agent and pastoral lease broker who had specialised in the sale of pastoral leases in Western Australia for decades. He had been involved in dozens of sales over the years. This reflects the limited number of pastoral property sales disclosed by the Landgate statistics discussed previously.

Pastoralist one was a person who had inherited his property. He had been directly involved in the pastoral industry for about 20 years and indirectly involved through his family for his entire life.

He was familiar with the hypothetical case put to him and had heard of similar transactions, but he had never been involved in the sale of a property other than transfers within the family. In addition, he was not entirely familiar with Australian capital gains tax provisions and exemptions.

75 Sydenstricker-Neto, above n 67. 
He remarked that he would not purchase the station described in the hypothetical case. He said he did not trust the figures presented and said: ${ }^{76}$

I wouldn't buy the station. Not unless I was present at that muster, and therefore present every day after until the end of the six weeks until the transfer occurred, that sale transaction would not be current as it has been highlighted recently, numbers differentiate between what is so-called 'on the books' and what is on the property.

His concern as to numbers of cattle transferred was focused on the quid pro quo of the transaction rather than the categorisation of breeding stock and livestock for trade and is beyond the scope of this research, but he makes a valid point. The numbers and value of animals are extremely fluid. That is a central focus of AASB 141, discussed earlier.

As to stock on hand and the allocation of proceeds from the sale of the property, he made this observation: 77

Right, cows, you would count cows and you don't count calves. You just count cows and anything over weaners. Your cow/calf units are usually classed as, are just put in as cows. You just count them as whatever they are like at the going price at a recent sale. Roughly would be an indicator but usually most stations are sold on a head number.

You don't actually put a value on the homestead, furniture and such for the price of the sale. That comes later when you divvy it up. But usually, cattle stations are sold as a 20,000-unit cattle place which would go for about two times the current value at the stage of a cow which is probably near enough to about $\$ 2,000$ a head.

He elaborated on the allocation of funds for the sale of the property and suggested the following method of categorisation: ${ }^{78}$

Well, you do then design a value to which would bring that capital of expenditure on the animals back from $\$ 2,000$ a head, which is what you would be buying the station at and then you would divvy ${ }^{79}$ it off to the market value for the graders or market value for the infrastructure but, really, it is sort of designed; the pastoral lease is actually designed as how many cattle are on there, and that is why you pay a higher price per cow.

In the event the property was unstocked, he considered the concept of 'potential value'. He said "potential value is what you would be looking at then. So, it would have a value of the plant, the value of the lease and the value of the vegetation of what you are going to graze". 80

He saw no distinction between stud or breeding stock and livestock bred for sale. He suggested that all animals were the same - ultimately, they were all going to be sold. He said: ${ }^{81}$

Herd bulls go on the truck just as easy as normal bulls. They could be broken down. ${ }^{82}$ Once they go on the truck, their value really diminishes but their value diminishes once you buy them and put them on a pastoral lease.

He elaborated. ${ }^{83}$

Well, you go and buy a $\$ 6,000$ bull, whose kilo value is probably let's say $\$ 2$ a kilo, and he's weighing in at eight hundred kilos which is commercial down at ahh, put him across the Muchea floor, ${ }^{84}$ the saleyard floor would be a

76 Interview with Participant P 6 (Telephone Interview with Alexander Robert Fullarton, Curtin Law School, 30 June 2019).

77 Participant P 6, above n 76.

78 Participant P 6, above n 76.

79 An Australian colloquialism for 'divide' or share out.

80 Participant P 6, above n 76.

81 Participant P 6, above n 76.

82 Become sterile.

83 Participant P 6, above n 76.

84 Livestock saleyards near Perth in Western Australia. 
value of sixteen hundred dollars; as soon as you get into the pastoral country, anything could happen to him. It's just about a direct write-off, really, once they get to the pastoral region. They can break a dick, get a seed in there or whatever and become useless.

This participant's view strongly supports the view held in the Wade Case and that of the ATO.

The vendor had recently conducted and settled a sale for and on behalf of the estate of a deceased person and was very familiar with the process. She had also been a settlement agent in Western Australia for many decades and was very familiar with the process of transfers of property. She had been involved in the lodgement of the final income tax return in relation to the estate and had successfully appealed the original assessment, which had been prepared and lodged by an accountant.

The original income tax return and assessment considered that ALL livestock were trading stock in accordance with the general ATO opinion supported by the Wade Case. ${ }^{85}$ She appealed on the basis that ALL of the trade livestock had been mustered and removed from the property in a separate transaction. ALL of the remaining animals were either those of no commercial value or a breeding stock for the continued operations of the property.

She stated: ${ }^{86}$

I feel that they should have treated as part of the infrastructure necessary to run the station. I think it is fair and reasonable that the cattle that were sold at muster [to be treated as trading stock]. That a complete muster was done so those ones were trade cattle. Yes, they were part of the income for that financial year but the cattle which remained.

Bearing in mind that for a pastoral lease, it is one of the - it is essential, it is part of the infrastructure that you have to keep a base amount of cattle there; otherwise, it is not a workable concern. You have to do this to comply with the pastoral lease and in addition, those breeding stock are absolutely necessary to maintain the running of the station, and if you don't maintain the running of the station, I mean, for example, if you sold every single animal, then you would not be complying with the terms of your pastoral lease anyway. So, I think they are integral to the running of the station and the lease.

She supported her argument by noting that a requirement of a pastoral lease in Western Australia is that a minimum operational stock level must be maintained. The stock mustered and sold immediately prior to the sale had been treated as trading stock in the livestock trading account. Those of no commercial value were taken up by the purchaser at that value, and any profit from the sale of that stock would be reflected in the purchaser's livestock trading account. That accounting perspective appears to be in compliance with AASB 141 discussed previously.

The amendment was accepted on review, and the capital gains tax concessions accompanying the CGT levied on the sale of the breeding stock was accepted by the ATO. It is noted that the distinction between livestock for trading purposes and animals kept for production had been clearly and distinctly classified with supporting statistics, registrations and other supporting documentation.

This participant had made the distinction between stud or breeding stock and livestock for trade and had argued her case accordingly, with supporting documentary evidence.

85 Lendon, above n 12.

86 Interview with Participant P 3 (Telephone Interview with Alexander Robert Fullarton, Curtin Law School, 13 March 2019). 
The pastoral lease broker was a Western Australian business broker with decades of experience focussing on the sale of pastoral leases. He was aware of the distinction between livestock held as trading stock according to ordinary concepts and livestock retained by farmers for the purpose of breeding.

However, he said that he did not make the distinction when dealing with the sale of pastoral leases and farming properties and was also negatively critical of the United States concept of a timing criterion to distinguish breeding stock from livestock. ${ }^{87}$

Anecdotally, it is believed that in the United States, animals are classified according to their age: all younger animals (less than 12 months old) are considered livestock for trading, and those older than 24 months are deliberately kept for breeding.

This participant said "That is a bloody stupid idea. What happens in the case where you have a three-year-old steer? Surely you can't consider a steer as breeding stock, no matter how old it is." ${ }^{88}$ In response to the question, "Why are you holding a steer for more than two years?" He replied, "It simply hasn't hit trade weight yet. But it will be sold as soon as it is." 89

It is suggested that his opinions may be due to a misunderstanding of IAS 41, or an interpretation of how the United States livestock industry operates. Examination of that concept is beyond the scope of this research, but the timing structure for continual valuation, under the provisions of IAS 41 and AASB 141, might give some substance to that understanding.

In the Australian experience, where much livestock is held on unimproved rangelands, it may take many years for beasts to reach a commercially viable trading weight. Therefore, the United States timing criterion may not be a reliable indicator of breeding/trading stock classification diversity.

When questioned as to how he had come to understand and actively discriminate between animals used as breeding stock and trading stock, he said he was also an experienced farmer and therefore well acquainted with the minutiae of classification of farm animals.

He stated that he not only listed livestock according to breeding and trading stock on negotiated contracts of sale, but he also appended a schedule of inventory which classified livestock according to type, such as cows with calves, heifers, weaned calves, steers, bulls and the like.

However, he said the sale price was normally agreed upon by negotiating a gross sale price. ${ }^{90}$

What we tend to do is just come up with a number that is across the board — an average across the board and put a price to it. Not necessarily per head but put a value to all the stock in one lump. That's how we normally do it.

You know our values are arrived at by what sort of breeding stock the properties can run, and you know what's on the property at the time, and usually it's a guestimate because we can only go on current mustering figures. You know mustering figures which may be six months old. And then sometimes you estimate some calves. You estimate what may or may not be there. ... That can be done. I'm not suggesting it can't be done, but as a general rule, you would just be going with a lump sum for the livestock.

87 Fischer and Marsh, above n 57, at 59. Fischer and Marsh did not consider neutered or sterilised animals.

88 Interview with Participant P 2 (Telephone Interview with Alexander Robert Fullarton, Curtin Law School, 4 July 2017).

89 Participant $\mathrm{P} 2$, above $\mathrm{n} 88$.

90 Participant P 2, above n 88 . 
He advised that he had developed the practice of livestock classification and the appendix of the inventory through many years of experience. That experience was not only as a farmer but also industry experience in conducting rural property sales.

He pointed out that he had not adopted the practice from attending industry forums or training from real estate industry bodies to gain that method of sales practice, although the concept of an itemised list of stock or 'stocktake' is not uncommon. As far as he was concerned, his method of dealing with livestock was simply a matter of professional due diligence and the correct approach to documenting the sale of rural properties.

It is rather common practice for the sale of businesses in Australia to conduct a stocktake at the point of transfer of ownership of the business. ${ }^{91}$ Most businesses are transferred subject to an itemised list and valuation of stock at the point of transfer. It is therefore unusual to encounter a different practice for the transfer of stock in the case under review.

This participant also made the distinction between stud or breeding stock and livestock for trade. He also stated that the distinction should be supported with sound documentary evidence but considered that record keeping and account keeping were beyond his role as a broker.

I am just aware that there is a transaction levy when stock are transferred and whether they are breeding stock or whether they are stud stock or whatever they are. I am not aware of a difference. There may well be a difference and probably that might be sorted out by the accountants, but we don't get involved with that.

He made several other comments to illustrate that the accounting and taxation implications were beyond his role and responsibility:

And, you know the accountants get involved with that as well. Cos you know there's taxation implications, so you know they can adjust those numbers according to tax. You know according to the situation of the company or the vendor or the buyer.

He added:

They [the vendors and the purchasers] can deal with all that stuff, you know, through their taxation and through their accountant. We don't get involved in that. We leave all that to the accountants to work all that through.

The purchaser of a pastoral lease in the Gascoyne district said he was not familiar with the capital gains provisions and exemptions that exist under Australian law. He said he considered all animals on pastoral properties 'to be solely as tradeable stock.' ${ }^{92}$

He said: ${ }^{93}$

Well, you know, it depends on how you want to cull. Basically, they will all be traded before they die anyway, don't they? So yeah, obviously, plant has been what's required to actually operate with machinery, fencing, water infrastructure. Whereas your livestock are basically that is what we are doing it for - is that you are breeding animals either for wool meat or otherwise. So, my understanding of the plant is, yeah, is what is required to be able to carry out that operation in the first place.

91 D Magarey, Buying and Selling Businesses and Companies (Butterworths, 2nd ed, 1989) 54.

92 Interview with Participant P 1 (Interview with Alexander Robert Fullarton, Curtin Law School, 22 December 2018).

93 Participant P 1, above n 92. 
In answer to the question, 'So, the stock on the station from which you breed, would you consider them still to be tradeable stock even though you are breeding with them?' He answered: ${ }^{94}$

Yes, because you know there might be a season like a dry season where you have to actually sell animals, you know what I mean? So, in the day you might sell; you might put that money away, for example, and you might buy back in once the season has improved. So, I guess at the end of the day that you know you might sell an animal and buy a replacement in later at a cheaper price. In which case, obviously, there is a profit consideration there, or otherwise there might well be a, you know, a loss in that type of transaction.

It is noted that the scenario he gave as an example is almost identical to the facts considered in the Wade Case. He described his method of livestock control in reasonable detail: ${ }^{95}$

Part of the herd will be considered as breeding stock, you know, obviously you will have, say, breeding stock will be culled for age. When they are due, they will go anyway. And then obviously you will have your saleable animals which are, generally speaking, will be the offspring of your breeders anyway.

My, the way I would operate is that obviously your female animals, you would carry them through until you cull for age. Your male animals with the example of cattle ... you would sell them either as, you know, bulls or steers. For sheep, [that] would be [that] you would actually wether ${ }^{96}$ them when they are younger, and so you are still going to keep your breeding stock separate to your saleable animals.

His perspective was that ultimately ALL animals go to market sooner or later, so therefore, they are always considered trading stock regardless of their age.

He did make a single exception: animals kept as part of the breeding stock on the purchase and sale of pastoral properties might be considered capital, but only when transferred in association with the transfer of the entire property: ${ }^{97}$

I think that's generally what you sell is to me that's what makes the operation what it is. It should be your revenue. It is where you get your income from. The only way I would consider it a capital gains type scenario is if, say, you bought animals when you bought a property with animals at a certain value and then on the sale of that property, you know what the value was at the time, but anything as far as an annual turnoff is, in my eyes, is just purely revenue.

Pastoralist two was another person who had inherited his property, although he pointed out that despite the transfers being within the family, they involved the purchase and sale of the property. The property was formally purchased from his parents as part of a distribution of their estate. Interested parties such as siblings were entitled to their share of the estate, and parents were 'paid out' on their retirement.

Hence, while the transfers were between related parties, the purchase and sale were reasonably close to a commercial transaction on the open market to ensure 'fair value' to all concerned.

He was aware of the distinction between breeding stock and livestock for sale but considered all livestock as trading stock. He commented that he would rather not have to sell his breeding stock but added, "well, if it's dry enough, you have to sell everything, but that has never happened to us". ${ }^{9}$

94 Participant P 1, above n 92.

95 Participant P 1, above n 92.

96 Castrate.

97 Participant P 1, above n 92.

98 Interview with Participant P 7 (Interview with Alexander Robert Fullarton, Curtin Law School, 22 July 2017). 
He said "I wouldn't put those cows on the truck unless I was forced to. Because they are more valuable to me breeding than what I can get for them." ${ }^{\prime 99}$

He added: ${ }^{100}$

I will rarely sell a one of my better calves or cows that's within age. Because the sale price never reflects genetics effectively. If she is a cow that is breeding successfully, she's the one that I want to keep. If she's had calves every year and she'll continue to for the next few years, I will definitely be keeping her.

He did not view her as trading stock and said he treated 'trade cows' and 'breeding cows' separately: ${ }^{101}$

I count them as a 'Bush' cow, which means a breeding cow. Yeah. The cows that I don't want to keep I call a 'Cull' cow, and they'll be there for sale. If I call them a breeding cow, if I go through a muster and I say I draft, and I say 100 breeding cows, I say that I am definitely going to breed from in the next year.

The ones that I don't want are spayed and some of the old ones I will spay (sterilise) them as well, and I will sell them at that moment or later when they are fatter.

However, ultimately, all cattle on his property were sold. He said, 'I don't like cattle to die. I don't want them to die [on my property]. A dead cow is basically $\$ 1,000$ wasted in the paddock.' ${ }^{102}$

He suggested that apart from the economic consideration of lost income, there was also an animal husbandry influence. He considered it far more humane that the animal be slaughtered in a humane fashion than perish in the heat of old age far from the nearest shade and comfort of a water hole.

He was aware that one line is classed as revenue, and the other is classed as capital gains, but he did not know a lot about it, although he had never had to sell a property.

He added the following comment:

There is a factor often overlooked by many pastoralists. It is the information of the land contained in the memory of the herd. I am talking about the knowledge that the cattle have of the land.

I believe that it is not just a learned thing as a calf learns from its mother but I think it is somewhat genetic. It is knowledge passed from as far back as 20 generations or so.

It is the knowledge of the land that allows the herd to prosper and develop, not merely survive and exist. It is such things as the tannin in the vegetation that can vary from morning to evening. The cow knows how the vegetation changes subtly throughout the day. Something palatable in the late afternoon might be sour in the morning.

They not only know the lay of the land of when and where to go to for water but how to use the hills and the plains for refuge for grazing or hiding from the sun, or how to stay warm in different places or cool when it needs to. That knowledge is critical and cherished by pastoralists. Dead cattle are a lot more than just the loss of a thousand dollars that are a loss of a lot of resources - including what I call Bush knowledge.

If you purchase cattle from other regions, they do not know how to get around on your station or the subtle difference on YOUR pasture. I have even noticed the difference when I have bought in cattle from next door. The country changes in ways that even we don't notice - but the cattle do.

That resource is VERY precious and could never be considered by me as mere 'trading stock'; it is a capital resource and not for sale.

99 Participant P 7, above $\mathrm{n} 98$.

100 Participant P 7, above n 98.

101 Participant $\mathrm{P} 7$, above $\mathrm{n} 98$.

102 Participant P 7, above n 98. 
I don't know if that is an accounting thing. I don't know much about that side of things but it is extremely important to me, and as far as I am concerned, it is a capital asset.

It is noted that although stating that ultimately all cattle on his property were to be sold, pastoralist two made a clear distinction between livestock for sale as trading stock and those kept for breeding purposes as capital assets.

However, it is also clear that breeding stock on his property would change their status from capital assets to trading stock at the end of their 'working' life. That change of status is addressed in IAS 41 . He did conclude that the classification was an accounting function and beyond his scope of expertise.

Given that the role of accountants as financial and accounting advisers has been referred to by three of the participants above, the responses of two accountants familiar with the sale of farming properties are presented.

The rural accountant from northern Victoria was familiar with rural sales and had been involved in finalising accounts and the preparation of income tax returns on a regular basis. But he said he had never carried out any physical inspections of properties or had direct coordination with estate agents or been asked for advice prior to the sales.

He said he had "limited input into dissecting potential sale price into tax effective categories. [His] usual involvement is for preparing tax returns only after the property sale has settled." 103

The urban public accountant from Perth in Western Australia said he understood what the transaction was about and that he had prepared accounts and income tax returns for a few farms in the late 1980s and early 1990s. However, he had never been associated with the sale of a pastoral lease in the Outback.

He also said he had never been consulted as to the dissection of the sale price or how the funds had been allocated for the purchase of separate items such as plant, buildings, land, livestock and the like.

When asked if he had been consulted as to how to allocate the sale funds, he said: ${ }^{104}$

No, it wasn't done that way because the sale was really dictated by the documentation, and my recollection is that the documentation treated all as trading stock by the client and also by the stock agents in selling it, and I don't recall it being separated as, you know, breeding stock x amount than number of head, as opposed to the normal trading stock. I think it was all included in the one, so I suspect I would have treated it that way - following the documentation.

He added: 105

But had I been asked, and that was all in hindsight too, we would have seen it 12 months later after the event, and it would have been impractical to try and change the transaction well and truly after that. I wasn't asked at the beginning but I have given it some thought over the years, and I know that with some other similar type things, we have particularly made a point of separating the breeding stock in valuation and number in the contractual arrangements to the normal trading stock. That's how I believe if I was asked, that's how I would put it.

It appears that despite the belief of vendors, brokers and some pastoralists that the accountants/tax preparers are consulted for their opinions on the classification and treatment of sale proceeds on the transfer of pastoral leases before and during the process of sale, they are not consulted. The examination of the

103 Interview with Participant P 5 (Telephone Interview with Alexander Robert Fullarton, Curtin Law School, 30 June 2019). 104 Interview with Participant P 4 (Telephone Interview with Alexander Robert Fullarton, Curtin Law School, 5 June 2019).

105 Participant P 4, above n 104. 
broader accounting profession is beyond the scope of this research, but this article suggests that could be a topic for future research.

This study suggests that stakeholders in the ownership, transfer, administration and record keeping of animals on pastoral properties are aware of a distinction between stud or breeding stock and livestock for sale as trading stock, but ultimately, they do not account for them as such. It appears that the reliance on professional accounting advisers may be somewhat misplaced, as those advisers do not appear to be consulted in a timely fashion but are instead faced with a fait accompli.

It also appears that all stakeholders adopted the view that ultimately ALL livestock are sold and therefore are ALL trading stock. One pastoralist expressed that view; however, most participants considered that breeding stock should be considered as capital assets.

It appears that they may have overlooked the criteria for capital assets that says they are primarily held for more than one accounting period, not that they are never disposed of. Capital assets are often eventually sold and rarely held until destruction. As the value of a capital asset is reduced over many accounting periods by way of a provision for depreciation, the sale of a capital asset can, and often does, give rise to a capital gain. Hence the concept of a capital gains tax.

This article suggests it is the complexity of recording and accounting for separating the two classifications that may be an obstacle to the distinction of some livestock being regarded as capital assets. It is simply extremely convenient, for many reasons, for stakeholders to treat ALL animals as livestock for trading purposes.

This article focuses on the definition of livestock as a capital or revenue classification, and there does not appear to be a reason suggested by accounting convention that ALL animals be classified as livestock for trading purposes. The ATO uses the case of Federal Commissioner of Taxation $v$ Wade ${ }^{106}$ to substantiate its view. A detailed examination of the Wade Case is conducted in the companion article. ${ }^{107}$ It indicates that rigid adherence to the Wade Case to support the ATO's broader interpretation of the finding - that ALL livestock are trading stock - might be unsafe.

\subsection{RESEARCH FINDINGS, CONCLUSIONS, LIMITATIONS AND SUGGESTIONS FOR FURTHER RESEARCH}

This article challenges the view held by the ATO, and nearly half of the accountants and tax preparers in Australia, that ALL animals in a primary production business are considered livestock for the purposes of the trading stock provisions of the ITAA 1997.

The impact of that view is that retiring pastoralists and farmers are levied income tax at ordinary rates on the proportion of animals held for breeding or stud purposes as part of the business. The ATO view denies retiring pastoralists and farmers certain exemptions and concessions permitted under the CGT provisions. Instead, they have to pay the higher personal income tax rates assessed on income according to ordinary concepts.

Further, the funds received for the portion of the sale attributable to breeding stock is considered as ordinary income in the year of the sale of the property. In the ordinary course of business, pastoralists

106 [1951] HCA 66; (1951) 84 CLR 105.

107 Fullarton and Pinto, above n 1. 
and farmers would very rarely sell their entire holding of stud stock. That only occurs due to exceptional circumstances such as droughts or as part of disease-prevention measures.

It is argued that animals kept for breeding purposes are capital assets, and therefore the proceeds of the sale of those animals, in conjunction with the sale of the property and the other assets contained thereon for the purpose of operating the business, are capital sales. Thus, that proportion of the proceeds of the sale of the primary production business should be subject to CGT provisions and taxed accordingly.

To support its argument, this article has considered the accounting definition of a capital asset and finds that a capital asset is property or a right that exists for the benefit of the enterprise to produce revenue over more than one accounting period. Animals held for the purposes of producing saleable products, such and milk and wool, or other animals for slaughter are intended to be held for a number of years.

It briefly considers the modern International and Australian Accounting Standards that relate to the valuation and accounting compliance requirements for the reporting of biological assets. It finds that IAS 41 and AASB 141 relate directly to animals held for the purpose of producing saleable products such as milk and wool. These standards have been introduced into Australian statutes since 2000 and were reviewed in 2019. They did not apply when the ATO view was formed based on the Wade Case in 1951.

Significant events since 1951 include the Asprey Report ${ }^{108}$ of 1975 which indicated that livestock could be considered as capital assets rather than trading stock. Capital gains tax, not in existence in 1951, was introduced in 1985. Further, accounting standards relating to biological assets have been introduced since 2000 .

In the companion article to this, it is argued that the findings of the Wade Case may have been somewhat misunderstood by the ATO in support of its firm view. Therefore, the ATO view may not be as relevant today as it was in 1951 .

This article concludes that despite the complexities of recording the transactions for accounting purposes and for taxation lodgement compliance, the matter of the distinction between animals held long-term for their produce rather than held in the short term for trading purposes should be reconsidered by the ATO, stakeholders and the accounting/tax professions. It also suggests that the adoption of AASB 141 will ultimately make that review essential.

However, it is noted that respondents and interviewees considered that in order to be in compliance with the tax accounting requirements, establishing the distinction between livestock as breeding stock and those as trading stock should be carried out, but ultimately, it is too hard; hence, the livestock trading account (revenue) option is adopted. That is despite most of them being aware of the CGT concessions.

This article acknowledges the difficulties of the rural and remote areas of Australia in which the subject activities are conducted and the relatively few stakeholders and professionals engaged in the transfers of pastoral and like properties in Australia. Those factors have had a considerable impact on the size of the population of surveyed respondents and interviewees engaged in this research.

The concept of equity is beyond the scope of this article. However, the Asprey Report suggests that treating all taxpayers the same can create injustice. Individuals engaged in the pastoral industry have spent most of their working life in remote locations and have endured harsh conditions with little compensation. The ATO view denies them the tax relief afforded to an urban-based business proprietor who sells his 
business which consists of inanimate plant rather than living animals but held for the same purpose manufacturing product for sale. That is an injustice.

Accepted for publication 18 November 2020 
